\title{
In situ Rb-Sr dating of glauconite in partially altered Cambrian sedimentary sequences
}

\author{
MEHRNOUSH RAFIEI ${ }^{1}$, STEFAN LÖHR ${ }^{1}$, OLIVIER \\ ALARD $^{1}$, JURAJ FARKAS ${ }^{2}$, ANDRE BALDERMANN $^{3}$ AND \\ GLENN BROCK $^{1}$ \\ ${ }^{1}$ Macquarie University \\ ${ }^{2}$ University of Adelaide - Metal Isotope Group (MIG) \\ ${ }^{3}$ Graz University of Technology \\ Presenting Author: stefan.loehr@mq.edu.au
}

Glauconite is an authigenic clay mineral that is common in marine sedimentary sequences, typically presenting as $\mathrm{mm}$-scale pellets that have formed in equilibrium with seawater-derived pore fluids within $<100 \mathrm{ka}$ of sediment deposition. Glauconite geochronology has a long history but has fallen into disfavour due to the difficulty of obtaining 'pure' glauconite separates, resulting in contamination by older detrital phases or younger alteration phases, as well as post-depositional disruption or resetting of the $\mathrm{Rb}$-Sr isotope system during burial diagenesis. Recent advances in sedimentary petrography and reaction cell mass spectrometry now permit rapid in-situ $\mathrm{Rb}-\mathrm{Sr}$ dating of carefully screened glauconite grains, potentially resolving the limitations of traditional glauconite geochronology. Here we investigate the impact of burial alteration on glauconite $\mathrm{Rb}-\mathrm{Sr}$ systematics. We combine petrographic and geochemical characterisation with in-situ LA-ICP-MS/MS Rb-Sr dating of a range of altered and well-preserved glauconite grains in lower Cambrian sedimentary sequences from South and Central Australia. Seemingly 'pristine' grains are readily distinguished petrographically from illitised grains but geochemical screening reveals abundant subsurface secondary carbonate and apatite inclusions even in 'pristine' grains so that we employ a combined petrographic and geochemical screening approach for the construction of alteration-class specific isochrons. We find that primary apatite-bearing 'pristine' glauconite hosted in a clay-rich impermeable sample returns an age within error of the expected stratigraphic age, whereas carbonate hosted 'pristine' glauconite consistently returns younger ages. Geochemicallyscreened, inclusion-free compositions of 'pristine' and 'illitised' grains overlap and show similar ranges of ${ }^{87} \mathrm{Sr}$ loss as well as $\mathrm{Rb}$ $\mathrm{Sr}$ ages that are younger than the expected stratigraphic age, indicating cryptic alteration and/or subsurface intergrowth of illitised and unaltered glauconite domains. Illitised grains containing apatite and/or calcite/dolomite inclusions, by contrast, commonly contain unexpectedly radiogenic $\mathrm{Sr}$ resulting in $\mathrm{Rb}-\mathrm{Sr}$ ages closer to and at times older than the expected stratigraphic age. We attribute the apparent enrichment in ${ }^{87} \mathrm{Sr}$ and thus older ages to dissolution of detrital phases during burial diagenesis which releases radiogenic $\mathrm{Sr}$ that is incorporated by diagenetic apatite and carbonate. Ongoing work aims to more fully constrain the influence of host lithology, grain fabric and pore fluid physiochemical properties on glauconite alteration. 